\title{
AKRUAL
}

Jurnal Akuntansi

http://journal.unesa.ac.id/index.php/aj

\section{IMPLEMENTASI SISTEM PENGUKURAN KINERJA AKTIVITAS \\ GREEN SUPPLY CHAIN MANAGEMENT (GSCM) (Studi Kasus: KUD "DAU")}

\author{
Al Wafdah Lazuardian \\ Universitas Negeri Surabaya \\ lazuardianwafdah@gmail.com
}

\begin{abstract}
Abstrak
KUD "DAU" merupakan salah satu sektor industri yang memiliki aktivitas supply chain dalam memproduksi susu pasteurisasi yang diberi nama Dau Fresh Milk. Selama ini, KUD "DAU" belum pernah membuat pengukuran kinerja manajemen rantai pasokan yang ramah lingkungan. Oleh karena itu, diperlukan suatu metode yang diterapkan dalam mengukur kinerja SCM yang ramah lingkungan. Penelitian ini bertujuan untuk mengukur tingkat pencapaian kinerja manajemen rantai pasokan KUD "DAU" yang ramah lingkungan. Metode yang digunakan untuk mengukur kinerja SCM adalah metode pendekatan hijau ramah lingkungan untuk manajemen rantai pasokan (GSCM). Model pengukuran kinerja GSCM terdiri dari kegiatan pengadaan hijau, green manufacturing, green distribution logistics. Pengamatan diperoleh dari sejumlah 44 indikator yang mengukur indikator kinerja utama yang valid. Dari pengukuran tersebut dapat diberikan rekomendasi perbaikan indikator kinerja yang memiliki kategori merah traffic light system.
\end{abstract}

Kata Kunci : Supply chain measurement, Green supply chain management, dan traffic light system.

\section{PENDAHULUAN}

\section{Latar Belakang}

Belakangan ini sektor industri telah berkembang serta melibatkan berbagai operasi bisnis serta aktivitas manufaktur yang dianggap sebagai salah satu kegiatan yang telah banyak memberikan efek perubahan pada lingkungan khususnya efek negatif yang terjadi pada lingkungan itu sendiri. Dampak lingkungan yang diakibatkan tersebut terjadi selama proses produksi berlangsung, dimulai dari pengadaan bahan baku, dilanjutkan dengan proses produksi, serta sampai pada tahap pemanfaatan kembali produk hingga pada tahap akhir (Zhu dan Sarkis, 2006). Berbagai persepsi muncul bahwa permasalahan lingkungan disebabkan oleh sektor industri, seharusnya mereka yang harus paham tentang penggunaan teknologi ramah lingkungan dalam siklus proses produksi yang dilakukan 
agar dapat meminimalisasi limbah yang secara tidak langsung juga akan menjaga keberlanjutan kebersihan lingkungan.

Sektor industri yang dianggap sebagai salah satu pelaku utama dalam permasalahan lingkungan, hendaknya menyadari pentingnya penggunaan teknologi yang ramah lingkungan dalam menjalankan proses produksinya. Sektor industri yang melakukan proses produksi, secara otomatis menjadi subjek atau pelaku sebagai rantai pasok itu sendiri. Setiap aktivitas tersebut, berpotensi untuk menciptakan polusi, limbah, serta bahan yang dapat berbahaya bagi lingkungan. Supply chain sendiri memiliki arti sebagai jaringan dari seluruh organisasi mulai dari pemasok sampai dengan ke pengguna akhir, yang terdapat berbagai informasi di dalamnya (Pujawan, 2005).

Supply Chain dapat diimplementasikan dengan Supply Chain Management (SCM). Saat ini, SCM mengalami perubahan diiringi dengan perubahan lingkungan yang telah menjadi sebuah isu global dalam industri khususnya sektor industri manufaktur. Isu tentang konsep industri telah memaksa sektor industri manufaktur melakukan penyesuaian dengan konsep industri hijau (green industries) dalam setiap proses produksinya. Perkembangan SCM tersebut akhirnya dikenalkan konsep baru yakni, Green Supply Chain Management (GSCM) dimana konsep ini sudah menggabungkan konsep SCM dan juga konsep industri hijau. GSCM telah muncul sebagai pendekatan baru yang penting bagi perusahaan untuk mencapai keuntungan dan pangsa pasar dengan tujuan mengurangi risiko dan dampak lingkungan (Van Hoek, 1999).

GSCM merupakan konsep manajemen rantai pasok tradisional yang terhubung dengan aspek lingkungan yang meliputi rancangan produk, pemilihan supplier, pengadaan bahan baku, aktivitas produksi, aktivitas pengemasan, aktivitas pengiriman produk ke konsumen, sampai dengan manajemen penggunan akhir produk (end-of-life product) (Sundarakani et al., 2010). GSCM bertujuan agar meminimasi limbah yang berupa energi, bahan kimia berbahaya, gas emisi, limbah di sepanjang jaringan rantai pasok yang terjadi sepanjang rantai pasokan. GSCM juga dapat didefinisikan sebagai green manufacturing (manufaktur ramah lingkungan), green procurement (pengadaan ramah lingkungan), green distribution (distribusi ramah lingkungan), dan reverse logistic (logistik terbalik) (Ninlawan et al., 2010). GSCM juga dapat mempromosikan efisiensi dan sinergi antara mitra bisnis dan pimpinan perusahaan serta membantu untuk meningkatkan kinerja lingkungan, meminimalkan limbah dan mencapai penghematan biaya (Rao dan Holt, 2005). 
Sebuah perusahaan pasti memiliki tujuan, di antaranya peningkatan kualitas merk, peningkatan pemanfaatan sumber daya, layanan pelanggan yang lebih baik dan peningkatan profitabilitas, peningkatan daya saing. Untuk mencapai tujuan organisasi tersebut, organisasi menggunakan berbagai macam strategi agar tujuan dapat tercapai. Strategi GSCM dapat menjadi salah satu upaya dan pilihan yang baik untuk menyeimbangkan lingkungan, ekonomi dan manfaat sosial (Diabat dan Govidan, 2011).

Akhir-akhir ini topik Green Supply Chain Management (GSCM) telah berkembang dan telah menjadi area penelitian yang semakin populer. Penerapannya pun sudah dapat diaplikasikan ke berbagai sektor industri, karena konsep ini adalah gabungan konsep SCM dan konsep green industries dimana kelangsungan atau kelestarian sumber daya sangat penting sehingga tidak memberikan dampak negatif terhadap lingkungan. Global warming, penggunaan zat kimia yang beracun serta menurunnya sumber daya yang lambat laun pasti akan habis. Beberapa organisasi telah menanggapi isu-isu lingkungan tersebut dengan menerapkan konsep GSCM itu sendiri. Prinsip-prinsip dalam organisasi mereka, seperti menggunakan bahan baku yang ramah lingkungan, menggunakan kertas daur ulang untuk kemasan, serta mengurangi ketergantungan pada minyak bumi. Dalam penerapan prinsip-prinsip GSCM telah diperluas ke berbagai departemen dalam suatu organisasi dan rantai pasokan. Penerapan GSCM ini sangatlah fleksibel dan dapat diterapkan oleh semua sektor industri, sehingga konsep ini juga sangat memungkinkan untuk diterapkan pada koperasi yang ada di Indonesia.

Koperasi Unit Desa (KUD) "DAU" adalah salah satu koperasi yang berlokasi di Malang, Indonesia, dimana koperasi ini merupakan industri manufaktur dan termasuk jenis koperasi yang mengolah bahan mentah menjadi barang jadi, yakni mengolah susu mentah yang diperah dari sapi perah kemudian akan diolah menjadi suatu produk berupa susu kemasan yang siap minum. Pada proses bisnis KUD "DAU" ternyata telah melibatkan berbagai aktivitas yang kompleks, mulai dari aktivitas pengadaan, proses produksi, kemudian aktivitas distribusi, sampai pada akhirnya aktivitas reverse logistic. Namun apabila dilihat dari rantai produksi dari awal sampai akhir masih banyak yang belum memerhatikan dampak yang ditimbulkan akibat aktivitas yang dilakukan atau bisa dikatakan sebagai aktivitas yang belum ramah lingkungan.

Aktivitas pengadaan bahan baku yang dilakukan oleh Koperasi DAU masih belum menerapkan sistem pengadaan bahan baku yang efektif dan efisien, sehingga jumlah bahan baku yang tersedia sering tidak sesuai dengan pemakaiannya. Aktivitas produksi ini bisa dilihat dari belum adanya Standar Operasional Prosedur yang tertulis yang 
diterapkan di dalam proses produksi, seperti belum adanya SOP proses pengolahan dan pengepakan susu pasteurisasi dan SOP pengolahan limbah yang masih sangat sederhana yang hanya mencampurkan limbah susu dengan air biasa kemudian dibuang ke sungai. Untuk aktivitas distribusi sendiri dapat dilihat dari pengiriman produk yang menggunakan alat transportasi tidak sesuai dengan kapasitas alat angkut, sehingga hal ini menyebabkan kurangnya efektivitas KUD "DAU” dalam proses distribusi produk yang akan merugikan KUD "DAU" sendiri. Selanjutnya apabila dilihat dari aktivitas reverse logistic, KUD "DAU" masih belum melakukan penanganan ulang terhadap kemasan plastik minuman yang beredar banyak di pasaran sehingga dapat menyebabkan dampak yang negatif terhadap lingkungan akibat adanya sampah plastik yang ditimbulkan.

Selain dilihat dari aktivitas rantai pasok yang terjadi, dapat disimpulkan bahwa KUD "DAU" belum menerapkan pengukuran kinerja GSCM. Maka dari itu aktivitas industri yang terjadi di KUD "DAU" secara langsung memberikan dampak terhadap lingkungan baik dampak yang bersifat baik maupun dampak yang bersifat buruk bagi lingkungan. Untuk itu perlu dilakukan suatu perancangan dan pengukuran kinerja terhadap aktivitas rantai pasok di KUD "DAU" yang menerapkan pengukuran kinerja Green Supply Chain Management yang ramah lingkungan. KUD "DAU" menjadi pilihan karena dengan pertimbangan KUD "DAU” memiliki rantai pasok yang lengkap dari awal sampai akhir. Selain itu, diantara industri produk makanan yang ada, KUD "DAU” dapat dikategorikan sebagai industri yang cukup stabil dan sudah cukup lama bertahan di industri manufaktur sehingga dapat melakukan peningkatan pada tahap pengembangan supply chain yang ramah lingkungan. Berdasarkan fenomena tersebut maka peneliti ingin melakukan penelitian lebih lanjut mengenai Implementasi Green Supply Chain Management di KUD "DAU”.

\section{KAJIAN PUSTAKA}

Supply Chain (Rantai Pasokan) adalah jaringan atau rantai sebuah organisasi. Mulai yang dimulai dari pemasok sampai dengan tangan pengguna akhir. Didalamnya terdapat aliran dan transformasi material, uang dan informasi (Pujawan, 2005). Green Supply Chain Management (GSCM) adalah dari konsep manajemen rantai pasok tradisional. Yang terhubung dengan aspek lingkungan yang terdiri atas merancang sebuah produk, memilih supplier, pengadaan bahan baku, aktivitas produksi, aktivitas pengemasan, aktivitas pengiriman produk sampai dengan ke tangan konsumen, serta manajemen penggunan akhir produk (end-of-life product) (Sundarakani et al., 2010). 


\section{METODE PENELITIAN}

Penelitian mengenai implementasi GSCM ini menggunakan pendekatan kualitatif dengan paradigma intrepretif. Bogdan dan Taylor dalam buku Moleong (2013: 4) mendefinisikan pendekatan kualitatif sebagai prosedur penelitian yang menghasilkan data deskriptif berupa kata-kata tertulis atau lisan dari orang-orang dan perilaku yang dapat diamati. Selain itu, Krik dan Miller mendefinisikan bahwa penelitian pendekatan kualitatif adalah tradisi tertentu dalam ilmu pengetahuan sosial yang secara fundamental bergantung dari pengamatan pada manusia baik dalam kawasannya maupun peristilahannya. Paradigma intrepretif menunjukkan bahwa peneliti bukan hanya menggambarkan sesuatu secara naturalistik melainkan juga memaknai atas fenomena tersebut.

Metode analisis yang digunakan yaitu Fenomenologi. Fenomenologi merupakan pandangan berfikir yang menekankan dan fokus pada pengalaman-pengalaman subjektif manusia dan interpretasi dunia. Penelitian dalam pandangan fenomenologis berusaha memahami arti peristiwa dan kaitan-kaitannya terhadap orang-orang yang berada dalam situasi tertentu (Moleong, 2013: 15-17). Penelitian ini merupakan penelitian kualitatif dikarenakan tujuan penelitian ini adalah untuk memahami pentingnya impementasi GSCM dalam dunia bisnis.

\section{Key Informant}

Kehadiran informan sangat diperlukan untuk mengetahui keakuratan dan keaktualan informasi. Kehadiran informan dapat memberikan informasi mengenai penelitian yang akan dilakukan. Informasi-informasi yang disampaikan oleh informan kepada peneliti, akan digunakan oleh penelliti sebagai data yang dapat dianalisis oleh peneliti. Pemilihan informan kunci merupakan hal yang sangat utama sehingga harus dilakukan secara cermat, karena penelitian ini mengkaji tentang pentingnya implementasi GSCM pada KUD "DAU". Dari informan kunci ini selanjutnya diminta untuk memberikan rekomendasi untuk memilih informan-informan berikutnya, dengan catatan informaninforman tersebut merasakan dan menilai kondisi lingkungan kerja sehingga terjadi sinkronisasi dan validasi data yang didapatkan dari informan kunci.

\section{Tahap Pengumpulan dan Pengolahan Data}

\section{Pengumpulan Data}

Teknik pengumpulan data merupakan cara yang digunakan peneliti untuk mendapatkan data dalam suatu penelitian. Pada penelitian ini peneliti memilih jenis penelitian kualitatif maka data yang diperoleh haruslah mendalam, jelas dan spesifik. Pengumpulan data dapat 
dilakukan dalam berbagai setting, berbagai sumber dan berbagai cara. Teknik pengumpulan data yang dilakukan dalam penelitian ini yaitu pengamatan dan wawancara.

McDrury (Collaborative Group Analysis of Data, 1999) seperti yang dikutip Moleong (2013:248) tahapan analisis data kualitatif adalah sebagai berikut:

a. Membaca/mempelajari data, menandai kata-kata kunci dan gagasan yang ada dalam data.

b. Mempelajari kata-kata kunci itu, berupaya menemukan tema-tema yang berasal dari data.

c. Menuliskan 'model' yang ditemukan.

d. Koding yang telah dilakukan.

Analisis data dimulai dengan melakukan wawancara mendalam dengan informan kunci, yaitu seseorang yang benar-benar memahami dan mengetahui situasi obyek penelitian. Setelah melakukan wawancara, analisis data dimulai dengan membuat transkrip hasil wawancara, dengan cara memutar kembali rekaman hasil wawancara, mendengarkan dengan seksama, kemudian menuliskan kata-kata yang didengar sesuai dengan apa yang ada di rekaman tersebut. Setelah peneliti menulis hasil wawancara tersebut ke dalam transkrip, selanjutnya peneliti harus membaca secara cermat untuk kemudian dilakukan reduksi data.

Peneliti membuat reduksi data dengan cara membuat abstraksi, yaitu mengambil dan mencatat informasi-informasi yang bermanfaat sesuai dengan konteks penelitian atau mengabaikan kata kata yang tidak perlu sehingga didapatkan inti kalimatnya saja, tetapi bahasanya sesuai dengan bahasa informan. Abstraksi yang sudah dibuat dalam bentuk satuan-satuan yang kemudian dikelompokkan dengan berdasarkan taksonomi dari domain penelitian. Analisis Domain menurut Sugiyono (2009:255), adalah memperoleh gambaran yang umum dan menyeluruh dari obyek/penelitian atau situasi sosial. Peneliti memperoleh domain ini dengan cara melakukan pertanyaan grand dan minitour. Sementara itu, domain sangat penting bagi peneliti, karena sebagai pijakan untuk penelitian selanjutnya. Mengenai analisis taksonomi yaitu dengan memilih domain kemudian dijabarkan menjadi lebih terinci, sehingga dapat diketahui struktur internalnya. Adapun data yang dibutuhkan dalam penelitian adalah rantai pasokan, persediaan bahan baku, aktivitas produksi, pmilihan supplier bahan baku, training tenaga kerja terhadap karyawan, pengiriman produk, distribusi produk, penolakan bahan baku dari supplier, aktivitas produksi harian maupun bulanan, penggunaan BBM serta penggunaan listrik. 


\section{Pengolahan Data}

Setelah peneliti mendapatkan data yang dibutuhkan untuk kebutuhan penelitian, setelah itu data tersebut akan diolah dengan menggunakan metode yang sesuai dengan permasalahan yang terjadi. Di bawah ini adalah tahapan-tahapan pengolahan data yang dilakukan.

1. Mengidentifikasi rantai pasokan KUD "DAU"

Tahapan ini dilakukan dengan mengamati sistem rantai pasokan yang ada di KUD "DAU".

2. Mengidentifikasi seluruh stakeholder KUD "DAU"

Tahapan ini akan berpengaruh tehadap penentuan Key Performance Indikator (KPI) yang dapat diterapkan didalam perusahaan. Penentuan stakeholder ini juga terkait dengan tahapan validasi KPI serta pempersentasean setiap KPI dengan metode AHP.

3. Menentukan Key Performance Indikator (KPI)

Dalam menentukan setiap KPI, peneliti akan merujuk terhadap penelitian terdahulu serta beberapa referensi jurnal yang berkaitan dengan GSCM. KPI yang telah ditentukan, nantinya akan digunakan dalam menentukan tingkat keberhasilan untuk mengukur kinerja perusahaan yang bersifat ramah lingkungan.

4. Validasi model pengukuran kinerja

Validasi dilakukan untuk memeriksa apakah model pengukuran yang telah dibuat oleh peneliti dapat menyelesaikan permasalahan atau tidak. Validasi dilakukan dengan metode face validity, yaitu meminta pendapat ataupun opini dari expert atau narasumber stakeholder terkait, yang memiliki pemahaman dan pengetahuan tentang indikator-indikator pada model pengukuran kinerja green supply chain management, sehingga model pengukuran benar dan dapat diterima oleh perusahaan.

5. Melakukan pempersentasean terhadap indikator-indikator yang telah tervalidasi menggunakan metode AHP.

Tahapan ini dilakukan dengan menggunakan metode AHP. Beberapa stakeholder terkait diminta untuk mengisi kuisioner untuk menentukan indikator yang berhubungan langsung dengan aktivitas green supply chain management. 
6. Mengukur kinerja Green Supply Chain Management pada KUD "DAU"

Setiap indikator yang telah tervalidasi pada tahap sebelumnya akan dilakukan pengukuran kinerja terhadap pencapaian perusahaan dari setiap indikator yang telah ditentukan. Dan hasil yang diperoleh dari pengukuran tersebut akan dilanjutkan dengan melakukan persentase.

7. Scoring System.

Data sesungguhnya yang berasal dari KUD "DAU" ditunjukkan dari kondisi sesungguhnya yang mencerminkan nilai pencapaian kinerja masing-masing KPI. Hasil pencapaian tersebut akan diperlukan untuk proses perhitungan Scoring System.

8. Evaluasi Kinerja Green Supply Chain KUD "DAU” dengan Traffic Light System. Pada tahapan ini dilakukan evaluasi terhadap hasil pencapaian KUD "DAU" apakah nilai dari masing-masing KPI sudah mencapai target. Sedangkan untuk Traffic Light System sendiri nantinya dapat diketahui apakah nilai dari KPI tersebut perlu adanya perbaikan atau tidak.

\section{HASIL DAN PEMBAHASAN}

\section{Identifikasi Key Performance Indikator (KPI)}

Pertanyaan yang disiapkan mengandung 55 KPI yang kemudian diberikan kepada pihak manajer KUD "DAU" yang dianggap paling mengetahui serta mengerti mengenai permasalahan dan kondisi, KUD "DAU" untuk dilakukan validasi. Setelah tahap tersebut telah dilakukan, kemudian peneliti mendapatkan sebanyak 44 jumlah KPI yang benarbenar valid sesuai dengan kondisi perusahan. Selanjutnya, dilakukan perhitungan scoring system, serta analisa Traffic Light System agar diketahui apakah indikator kinerja masuk pada kategori hijau, kuning atau merah sesuai dengan tahap pengolahan data yang telah dijelaskan diatas.

\section{Perhitungan Persentase}

\section{Persentase Perspektif}

Pada tahap pertama dilakukan pempersentasean pada empat perspektif GSCM, yaitu green procurement, green distribution, green manufacture, dan reverse logistic. Hasil pempersentasean perspektif dapat dilihat pada Tabel 1. 
Tabel 1. Pempersentasean Perspektif

\begin{tabular}{llc}
\hline & Perspektif & Persentase \\
\hline Green & Procurement (P) & $25 \%$ \\
Green Distribution (D) & $25 \%$ \\
Green & Manufacture (M) & $25 \%$ \\
Reverse Logistics (R) & $25 \%$ \\
\hline
\end{tabular}

Berdasarkan Tabel 1 terlihat bahwa semua pempersentasean perspektif memiliki persentase yang sama yaitu bernilai 0.25 yang berarti bahwa setiap perspektif memiliki tingkat kepentingan yang sama.

\section{Persentase Objektif}

Pada tahap kedua yakni dilakukan persentase pada setiap objektif dalam perspektif GSCM. Hasil persentase untuk masing-masing objektif dapat dilihat pada Tabel 2 berikut ini.

Tabel 2. Pempersentasean Objektif

\begin{tabular}{clc}
\hline Perspektif & \multicolumn{1}{c}{ Objektif } & Persentase \\
\hline Green Procurement (P) & Pemilihan supplier yang mengolah limbah & $51 \%$ \\
& pabriknya (P1) & $28 \%$ \\
& Efisiensi penggunaan raw materials (P2) & $17 \%$ \\
& Pemanfaatan raw materials (P3) & $22 \%$ \\
Green Manufacture (M) & Efisiensi penggunaan air (M1) & $17 \%$ \\
& Efisiensi penggunaan energi (M2) & $19 \%$ \\
& Efisiensi penggunaan raw materials (M3) & $22 \%$ \\
& Pengelolaan di lantai produksi (M4) & $9 \%$ \\
& Pengelolaan SDM (M5) & $6 \%$ \\
& Pemanfaatan kembali limbah (M6) & $3 \%$ \\
& Pemakaian kemasan yang ramah lingkungan & $13 \%$ \\
& (D1) & $19 \%$ \\
& Distribusi produk (D2) & $24 \%$ \\
& Pemanfaatan tempat penyimpanan (D3) & $8 \%$ \\
& Penggunaan energi pada proses distribusi (D4) & $100 \%$ \\
\hline
\end{tabular}

Berdasarkan Tabel 2 dapat dilihat bahwa objektif dari tiap-tiap perspektif GSCM memiliki persentase yang berbeda. Dimana persentase paling tinggi dimiliki oleh tingkat redistribusi yang memiliki nilai $100 \%$, dikarenakan karena pada perspektif reverse logistic hanya memiliki 1 objektif. Sedangkan untuk perspektif lain yang objektifnya lebih dari 1 objektif memiliki nilai persentase yang beragam seperti hasil yang tertulis di atas. 


\section{Persentase KPI}

Pada tahap ketiga dilakukan persentase pada masing-masing KPI. Hasil persentase KPI dapat dilihat pada Tabel 3. Berdasarkan Tabel 3 didapatkan hasil bahwa KPI P301, D301, M101, D401, dan D501 memiliki persentase paling tinggi yakni dengan persentase $100 \%$.

Tabel 3. Persentase KPI

\begin{tabular}{|c|c|c|c|c|}
\hline Perspektif & $\begin{array}{l}\text { Objektif } \\
\end{array}$ & KPI & Kode & Persentase \\
\hline \multirow[t]{15}{*}{$\begin{array}{l}\text { Green } \\
\text { Procurement }\end{array}$} & $\begin{array}{l}\text { Pemilihan supplier yang } \\
\text { melakukan pengolahan }\end{array}$ & $\begin{array}{l}\text { Supplier susu yang } \\
\text { mengolah limbah }\end{array}$ & P101 & $50 \%$ \\
\hline & limbah & Supplie yang & P102 & $50 \%$ \\
\hline & $\begin{array}{l}\text { Pemilihan supplier yang } \\
\text { melakukan pengolahan } \\
\text { limbah }\end{array}$ & mengolah limbah & & \\
\hline & $\begin{array}{l}\text { Efisiensi penggunaan } \\
\text { bahan baku }\end{array}$ & $\begin{array}{l}\text { Susu segar yang } \\
\text { memenuhi SNI }\end{array}$ & P201 & $19 \%$ \\
\hline & & Gula & P202 & $13 \%$ \\
\hline & & Perasa coklat & P203 & $6 \%$ \\
\hline & & Perasa strawberry & P204 & $6 \%$ \\
\hline & & Perasa melon & P205 & $6 \%$ \\
\hline & & Perasa vanilla & P206 & $6 \%$ \\
\hline & Efisiensi penggunaan & Bubuk coklat & P207 & $6 \%$ \\
\hline & bahan baku & Pewarna melon & P208 & $6 \%$ \\
\hline & & Pewarna strawberry & P209 & $6 \%$ \\
\hline & & Kemasan 1 liter & P2010 & $10 \%$ \\
\hline & & Kemasan $180 \mathrm{ml}$ & P2011 & $12 \%$ \\
\hline & $\begin{array}{l}\text { Pemanfaatan Bahan } \\
\text { Baku }\end{array}$ & $\begin{array}{l}\text { Susu yang tidak sesuai } \\
\text { dengan SNI }\end{array}$ & P301 & $100 \%$ \\
\hline \multirow{7}{*}{$\begin{array}{l}\text { Green } \\
\text { Manufacture }\end{array}$} & Efisiensi penggunaan air & Air & M101 & $100 \%$ \\
\hline & Efisiensi penggunaan & Energi Listrik & M201 & $75 \%$ \\
\hline & energi & Energi BBM & M202 & $25 \%$ \\
\hline & $\begin{array}{l}\text { Efisiensi Penggunaan } \\
\text { bahan baku }\end{array}$ & $\begin{array}{l}\text { Efisiensi produksi } \\
\text { susu pasteurisasi }\end{array}$ & M301 & $26 \%$ \\
\hline & & $\begin{array}{l}\text { Efisiensi gula terhadap } \\
\text { susu pasteurisasi }\end{array}$ & M302 & $9 \%$ \\
\hline & & $\begin{array}{l}\text { Efisiensi perasa coklat } \\
\text { terhadap susu } \\
\text { pasteurisasi }\end{array}$ & M303 & $9 \%$ \\
\hline & $\begin{array}{l}\text { Efisiensi Penggunaan } \\
\text { bahan baku }\end{array}$ & $\begin{array}{l}\text { Efisiensi perasa } \\
\text { strawberry terhadap } \\
\text { susu pasteurisasi }\end{array}$ & M304 & $9 \%$ \\
\hline \multirow[t]{4}{*}{$\begin{array}{l}\text { Green } \\
\text { Manufacture }\end{array}$} & & $\begin{array}{l}\text { Efisiensi perasa melon } \\
\text { terhadap susu } \\
\text { pasteurisasi }\end{array}$ & M305 & $9 \%$ \\
\hline & & $\begin{array}{l}\text { Efisiensi perasa } \\
\text { vanilla terhadap susu } \\
\text { pasteurisasi }\end{array}$ & M306 & $9 \%$ \\
\hline & & $\begin{array}{l}\text { Efisiensi bubuk coklat } \\
\text { terhadap susu } \\
\text { pasteurisasi }\end{array}$ & M307 & $9 \%$ \\
\hline & & Efisiensi pewarna & M308 & $9 \%$ \\
\hline
\end{tabular}




\begin{tabular}{|c|c|c|c|c|}
\hline & & $\begin{array}{l}\text { melon terhadap susu } \\
\text { pasteurisasi } \\
\text { Efisiensi pewarna } \\
\text { strawberry terhadap } \\
\text { susu pasteurisasi }\end{array}$ & M309 & $9 \%$ \\
\hline & Pengelolaan di lantai & SOP Produksi & M401 & $67 \%$ \\
\hline & produksi & Mesin & M402 & $33 \%$ \\
\hline & $\begin{array}{l}\text { Pengelolaan sumber } \\
\text { daya manusia }\end{array}$ & $\begin{array}{l}\text { Pengelolaan } \\
\text { lingkungan }\end{array}$ & M501 & $20 \%$ \\
\hline & & $\begin{array}{l}\text { Jumlah karyawan } \\
\text { terhadap pengelolaan } \\
\text { lingkungan }\end{array}$ & M502 & $20 \%$ \\
\hline & & $\begin{array}{l}\text { Efektifitas karyawan } \\
\text { unit pengelolaan susu }\end{array}$ & M503 & $60 \%$ \\
\hline & Pemanfaatan limbah & Limbah cair & M601 & $33 \%$ \\
\hline & & Kemasan 1 liter & M602 & $33 \%$ \\
\hline & & Kemasan $180 \mathrm{ml}$ & M603 & $33 \%$ \\
\hline \multirow[t]{4}{*}{$\begin{array}{l}\text { Green } \\
\text { Distribution }\end{array}$} & $\begin{array}{l}\text { Pemakaian kemasan } \\
\text { ramah lingkungan }\end{array}$ & $\begin{array}{l}\text { Kemasan } 1 \text { liter daur } \\
\text { ulang }\end{array}$ & D101 & $50 \%$ \\
\hline & & $\begin{array}{l}\text { Kemasan } 180 \mathrm{ml} \text { daur } \\
\text { ulang }\end{array}$ & D102 & $50 \%$ \\
\hline & Distribusi produk & $\begin{array}{l}\text { Utilitas alat } \\
\text { transportasi }\end{array}$ & D201 & $50 \%$ \\
\hline & & Jumlah produk & D202 & $50 \%$ \\
\hline \multirow[t]{3}{*}{$\begin{array}{l}\text { Green } \\
\text { Distribution }\end{array}$} & Pemanfaatan storage & $\begin{array}{l}\text { Penggunaan tempat } \\
\text { penyimpanan }\end{array}$ & D301 & $100 \%$ \\
\hline & $\begin{array}{l}\text { Penggunaan energi pada } \\
\text { proses distribusi }\end{array}$ & $\begin{array}{l}\text { Penggunaan bahan } \\
\text { bakar }\end{array}$ & D401 & $100 \%$ \\
\hline & $\begin{array}{l}\text { Pemanfaatan produk } \\
\text { rusak }\end{array}$ & $\begin{array}{l}\text { Pemanfaatan produk } \\
\text { rusak }\end{array}$ & D501 & $100 \%$ \\
\hline Reverse & Pengelolaan Tingkat & Pengembalian produk & R101 & $16 \%$ \\
\hline \multirow[t]{2}{*}{ Logistic } & Redistribusi produk & Pemanfaatan produk & R102 & $44 \%$ \\
\hline & & $\begin{array}{l}\text { Pemanfaatan produk } \\
\text { susu yang } \\
\text { dikembalikan }\end{array}$ & R103 & $38 \%$ \\
\hline
\end{tabular}

\section{Sistem Penilaian}

Didapatkan 11 KPI yang masuk pada kategori merah karena persentase yang didapat sangatlah rendah berdasarkan perspektif green procurement dan 3 KPI termasuk dalam kategori hijau dengan pencapaian kinerja atas perspektif green procurement sebesar $61 \%$. Didapatkan 2 KPI berada dalam kategori merah pada green procurement, 8 KPI berada dalam kategori kuning, dan dalam kategori hijau terdapat 10 KPI dengan pencapaian kinerja perspektif green manufacture sebesar 56\%. Selanjutnya untuk 
perspektif green distribution didapatkan 2 KPI berada dalam kategori merah, 3 KPI berada dalam kategori kuning, dan 2 KPI berada dalam kategori hijau dengan pencapaian kinerja perspektif green distribution sebesar 65\%. Sedangkan untuk perspektif reverse logistics didapatkan hanya 1 KPI pada setiap kategori, baik pada kategori hijau, kategori kuning, dan juga kategori merah serta mendapat pencapaian kinerja perspektif reverse logistics sebesar 52\%. Hasil persentase di atas yang menunjukkan bahwa kinerja GSCM di KUD "DAU" perlu mendapatkan pengawasan yang lebih agar terdapat peningkatan kinerja pada KUD "DAU" dapat dinaikkan menjadi lebih baik lagi.

\section{Analisa Pembahasan}

Dari persentase di atas didapatkan bahwa terdapat 16 KPI berkategori merah, 12 KPI yang masuk dalam kategori kuning, dan 16 KPI yang berkategori hijau. Sementara beberapa KPI yang belum mencapai target, yaitu KPI pada kategori kuning dan merah harus diberi perhatian untuk meningkatkan kinerja green supply chain management KUD "DAU". Namun yang mendapat kategori warna merah yang perlu segera mendapatkan prioritas perbaikan, karena nilai pencapaiannya sangat jauh di bawah target.

Setelah dilakukan pengukuran dengan sistem penilaian, maka terdapat $16 \mathrm{KPI}$ yang berada pada kategori merah. Dan hal tersebut menandakan bahwa KPI tersebut menjadi prioritas utama yang perlu diperhatikan. Oleh karena itu, 16 KPI ini membutuhkan rekomendasi perbaikan agar terdapat peningkatan kinerja terhadap KPI yang berkategori merah tersebut. 16 KPI yang berkategori merah di atas adalah sebagai berikut:

1. KPI yang terdapat pada objektif efisiensi penggunaan bahan bakuu, yakni presentase penggunaan gula, perasa coklat, perasa strawberry, perasa melon, perasa vanili, pewarna melon, pewarna strawberry, bubuk coklat, kemasan 1 liter, dan kemasan 180 ml. ( KPI P202 sampai pada KPI P211).

Dalam melakukan pengadaan bahan baku KUD "DAU" hanya menggunakan perkiraan dari kepala unit dalam melakukan berapa jumlah pesanan bahan baku yang dibutuhkan dalam proses produksi. Hal ini menyebabkan adanya penumpukan jumlah bahan baku yang cukup besar dari tiap-tiap bahan baku yang ada. Namun, keadaan tersebut tidak sejalan dengan jumlah permintaan produk Dau Fresh Milk yang permintaannya fluktuatif, yakni permintaan akan meningkat tajam ketika 
musim liburan dan akan menurun ketika berada pada hari biasa. Ketika pihak KUD "DAU" melakukan pengadaan bahan baku yang kurang memperhatikan kondisi permintaan produk, hal ini yang menyebabkan adanya jumlah yang cukup besar dari masing-masing bahan baku setiap bulannya, dan akhirnya juga membuat terlalu banyak bahan baku yang menganggur di gudang.

2. KPI pada objektif pemanfaatan bahan baku, yakni pemanfaatan susu segar yang tidak sesuai dengan ketentuan SNI. (KPI P301)

Susu segar dikumpulkan setiap pagi dan sore hari dari peternak oleh KUD "DAU" perharinya. Dan dalam proses pengumpulan susu tersebut terdapat syarat yang harus dipenuhi oleh peternak, yakni ketentuan mutu susu segar berdasarkan SNI.

Proses pengumpulan susu yang dilakukan di masing-masing pos penampungan, dan didapat beberapa susu yang tidak sesuai dengan kententuan SNI. Beberapa dari susu tersebut tetap diterima oleh pihak KUD "DAU", namun susu terssebut tidak akan digunakan untuk diolah menjadi susu pasteurisasi dan juga tidak akan dikirimkan ke pihak luar. Susu yang tidak sesuai tersebut nantinya akan dibuang di pabrik. Susu yang dibuang oleh pihak KUD merupakan limbah yang dihasilkan oleh unit susu.

Pemeliharaan sapi yang tidak layak oleh peternak menjadi salah satu faktor penyebab adanya susu yang tidak sesuai standar SNI. Oleh karena itu, KPI ini perlu diperhatikan secara khusus karena dengan adanya limbah susu yang dibuang akan berdampak secara langsung ke lingkungan sekitar. KPI ketersediaan SOP dalam proses produksi yang terdapat pada objektif pengelolaan lantai produksi (KPI M401).

Sebuah proses produksi secara tidak langsung sangat bergantung terhadap Standar Operasional Prosedur (SOP) proses produksi. Namun, di KUD "DAU" selama ini belum ada SOP tertulis dari setiap tahap pengolahan susu pasteurisasi. Hanya untuk unit pengumpulan susu yang telah memiliki SOP secara tertulis, dan SOP tertulis tersebut telah disepakati dan diverifikasi oleh pihak luar yang bekerjasama langsung dengan KUD "DAU". SOP tertulis sangatlah diperlukan di unit pengolahan susu dalam memberikan pedoman dan pengawasan setiap karyawan agar setiap karyawan bekerja sesuai standar. Oleh karena itu, rekomendasi perbaikan yang perlu diberikan adalah pembuatan SOP dari setiap proses pengolah susu. Proses tersebut antara lain adalah pencampuran bahan, pasteurisasi, pendinginan susu, pengemasan, dan penyimpanan. 
3. KPI pada objektif distribusi produk : Ketepatan jumlah produk Dau Fresh Milk yang dikirimkan ke agen dengan total produksi, (KPI D202)

Data permintaan dari agen-agen penjual susu adalah menjadi acuan untuk menentukan jumlah produk yang akan diproduksi pihak unit pengolahan susu. Kemudian susu pasteurisasi yang diproduksi dari unit pengolahan susu pasteurisasi akan dikirimkan langsung kepada tiap-tiap agen. Namun, pada kenyataannya tidak semua agen tersebut menerima seluruh jumlah kiriman produk, karena jumlah persediaan yang ada di agen masih cukup banyak. Hal tersebut membuat ketidaksesuaian jumlah produk yang diproduksi dengan jumlah yang dikirimkan ke masing-masing agen dan berdampak bagi unit pengolahan susu yang harus menanggung kelebihan produk yang diproduksi dengan menyimpan kembali produk tersebut dan harus melakukan biaya pemeliharaan produk. Oleh karena itu diperlukan perbaikan untuk memperbaiki kekurangan KUD “DAU”. KPI Efisiensi penggunaan penyimpanan dalam penyimpanan produk susu pasteurisasi Dau Fresh Milk yang terdapat pada objektif pemanfaatan penyimpanan (KPI D301).

Produk susu Dau Fresh Milk yang tidak langsung dikirim ke agen menjadi persediaan yang disimpan oleh unit pengolahan susu dan unit pengolahan susu hanyalah memiliki penyimpanan yang berkapasitas 20.800 produk. Jumlah produk Dau Fresh Milk yang disimpan di penyimpanan berjumlah kecil setiap harinya. Dalam KPI ini dihitung tingkat efisiensi penggunaan penyimpanan yang berarti perbandingan jumlah produk yang disimpan terhadap kapasitas penyimpanan. Dan ternyata setelah dilakukan penghitungan didapatkan bahwa KPI ini mendapat nilai merah yang menunjukkan tidak efisiennya penggunaan penyimpanan. Hal tersebut akan menyebabkan kerugian karena harus mengeluarkan biaya tambahan berupa biaya pemeliharaan dengan menyalakan freezer dan penerangan yang ada di tempat penyimpanan tersebut. Disamping hal tersebut, karena sifat produk yang perishable maka diperlukan kehati-hatian yang lebih dalam hal penyimpanan produk.

Rekomendasi perbaikan yang diusulkan peneliti adalah dengan membagi gudang produk yang ada sebagai gudang bahan baku dan gudang produk. Karena selama ini, penyimpanan bahan baku kemasan hanya diletakkan di dekat pintu pabrik. Dengan adanya usulan rekomendasi perbaikan seperti ini diharapkan pemanfaatan gudang menjadi efektif dan efisien. 
4. KPI pada objektif pemanfaatan limbah : Pemanfaatan limbah cair yang dihasilkan (KPI M601).

Sebanyak 8.020 liter limbah cair dihasilkan di unit pengolahan susu, limbah tersebut berassal dari seluruh rangkaian proses produksi susu pasteurisasi, dari awal persiapan sampai pada tahap produk siap kirim. Limbah yang telah dihasilkan, akan dialirkan langsung ke penampungan limbah yang ada di pabrik tersedia. Penampungan tersebut dialiri air sungai agar limbah tersebut dapat ternetralisir dan tidak dimanfaatkan sama sekali serta langsung dibuang ke lingkungan sekitar (sungai) oleh pihak KUD "DAU". Hal inilah yang menyebabkan KPI ini mendapatkan nilai merah dan menjadi perhatian utama. Oleh karena itu, diperlukan rekomendasi perbaikan untuk KPI ini. Pemanfaatan produk Dau Fresh Milk (susu) yang dikembalikan yang terdapat pada objektif pengelolaan tingkat redistribusi (KPI R103)

Rekomendasi perbaikan yang diusulkan adalah meningkatkan kualitas produk, hal tersebut diharapkan nantinya dapat mencegah adanya pengembalian produk dari agen. Pemeliharaan kualitas produk dapat diterapkan dengan memeriksa setiap proses produksi dan menerapkan SOP tertulis yang telah dibuatkan sebelumnya dan mengimplementasikan serta meyakinkan bahwa SOP tersebut benarbenar dijalankan oleh para karyawan. Sehingga tidak akan ada pengiriman produk cacat kepada agen.

Dari analisis KPI-KPI diatas dirumuskanlah beberapa usulan rekomendasi perbaikan yang diberikan untuk 16 indikator kinerja yang mendapat kategori merah agar pencapaiannya sesuai dengan target yang diharapkan. Adapun usulan rekomendasi perbaikan yang dapat diberikan antara lain :

a. Membuat dan mengimplementasikan metode dalam merencanakan pembelian bahan baku seperti melakukan peramalan untuk mengetahui permintaan produk dan melakukan perencanaan MRP (Material Requirement Planning) serta melakukan upaya untuk meningkatkan kemampuan dan pemahaman karyawan mengenai teknik-teknik untuk melakukan perencanaan bahan baku yang tepat dengan melakukan pelatihan.

b. Memanfaatkan susu yang tidak sesuai dengan ketentuan SNI untuk digunakan atau dibuat sebagai bioethanol serta melakukan pelatihan secara berkala terhadap peternak dan pengawasan dari pihak KUD secara 
langsung dalam perawatan sapi, pemerahan, dan pengumpulan susu sehingga dapat meminimalisasi jumlah susu yang rusak.

c. Membuat SOP tertulis untuk setiap proses yang dilakukan pada rantai pasok, yakni dari awal sampai akhir proses produksi.

d. Melakukan komunikasi dan koordinasi antara agen dan unit pengolahan susu dalam mengelola pemintaan dan persediaan produk sehingga meminimalisasi kerugian salah satu caranya adalah dengan membuat kebijakan mengenai kesepakatan antara agen dan unit pengolahan susu terhadap produk susu.

e. Membagi gudang produk yang ada saat ini menjadi gudang produk dan gudang bahan baku sehingga kemasan yang biasanya berada di pintu masuk pabrik memiliki tempat penyimpanan sendiri.

f. Melakukan pemanfaatan susu yang tidak sesuai dengan ketentuan SNI untuk produksi bioethanol dan melakukan pemeriksaan terhadap produk dari awal proses produksi sampai akhir untuk dikirimkan ke pelanggan untuk memastikan tidak ada produk cacat yang dikirim ke agen.

\section{KESIMPULAN}

Dari hasil pengumpulan, pengolahan, serta analisis hasil yang telah dikemukakan sebelumnya, peneliti mendapatkan beberapa kesimpulan yaitu sebagai berikut :

1. Penerapan rancangan sistem pengukuran kinerja GSCM KUD "DAU" terdiri dari 4 perspektif yaitu green procurement, green manufacture, green distribution dan reverse logistic. Dari hasil pengukuran kinerja Green Supply Chain Management (GSCM) yang berdasarkan 4 perspektif GSCM diperoleh 44 Key Performance Indikator (KPI) yang valid, dimana KPI tersebut terdiri dari 14 KPI dari perspektif green procurement, 20 KPI dari perspektif green manufacture, 7 KPI dari perspektif green distribution dan 3 KPI dari perspektif reverse logistic. Semua KPI tersebut digunakan untuk mengukur kinerja green supply chain management yang ada di KUD "DAU”.

2. Sementara dari persentase dan traffic light system di dapatkan bahwa 16 KPI masuk dalam kategori hijau, 12 KPI masuk dalam kategori kuning dan 16 KPI masuk dalam kategori merah. Selain itu di dapatkan bahwa nilai pencapaian terbaik adalah dari perspektif green distribution dengan nilai pencapaian sebesar 6.45281, diikuti oleh perspektif green procurement dengan nilai pencapaian sebesar 6.109, kemudian perspektif green manufacture dengan nilai pencapaian sebesar 5.69, dan yang paling 
buruk perspektif reverse logistic dengan nilai pencapaian sebesar 5.2292. Selain itu juga, di dapatkan bahwa nilai kinerja GSCM KUD "DAU" sebesar 5.8836. Hasil perhitungan tersebut menunjukan bahwa kinerja masih berada pada kategori kuning yang berarti kinerja GSCM KUD "DAU" secara keseluruhan dapat dikatakan masih belum mencapai target baik. Sehingga KUD "DAU" harus berhati-hati agar kinerja GSCM tidak menurun dan perlu diberikan perhatian dan pengawasan yang lebih agar kinerja GSCM dapat ditingkatkan. 


\section{Daftar Pustaka}

Alhola, K.P. 2008. Promoting environmentally sound Furniture by green public procurement. Ecological Economics. Vol. 68, pp. 472-485.

Gaspersz, V. 2002. Production Planning and Inventory Control. Jakarta: PT. Gramedia Pustaka Umum.

Komarawidjaja, Wage. 2010. Optimalisasi Pemanfaatan Limbah Organik Sebagai Substitusi Media Kultur Mikroalga dalam Upaya Mereduksi CO2. Program Insentif DIKTI.

Lamming, R. \& Hampson, J. 1996. The environment as a supply chain management Issue. British Journal of Management. Vol. 7 No. 1, pp. S4562.

Ninlawan, C., Seksan, P., Tosappol, K. \& Pilada, W. 2010. The Implementation of Green Supply Chain Management Practices in Electronics Industry. Proseedings of the International Multi Conference of Engineers and Computer Scientists. Hongkong.

Pujari, D., Wright, G. \& Peattie, K. 2003. Green and competitive influences on environmental new product development performance, Journal of Business Research, Vol. 56 No. 8, pp. 657-671.

Sundarakani, B., Souza R. \& Goh, M. 2010. Modelling Carbon Footprints Across The Supply Chain. Internasional Journal Production Economics. 128, 43-50.

Tersine. Richard J. 1994. Principles of Inventory and Materials Management Fourth Edition. New Jersey: PTR Prentice.

Zhu, Q., Sarkis, J. \& Lai, K. 2005. Green Supply chain Management Implications for "Closing the Loop". Transportation Research Part E. 44(1), 1-18.

Zhu, Q., Sarkis, J. and Lai, K.H. 2008b. Confirmation of a measurement model for green supply chain management practices implementation, International Journal of Production Economics, Vol. 111 No. 2, pp. 261273. 